\title{
WHERE HAVE ALL THE YOUNGSTERS GONE? THE BACKGROUND AND CONSEQUENCES OF YOUNG ADULTS' OUTMIGRATION FROM HUNGARIAN SMALL TOWNS
}

\author{
Bernadett Makkai ${ }^{1}$, Éva Máté ${ }^{2}$, Gábor Pirisi $^{3}$, András Trócsányi $^{4}$
}

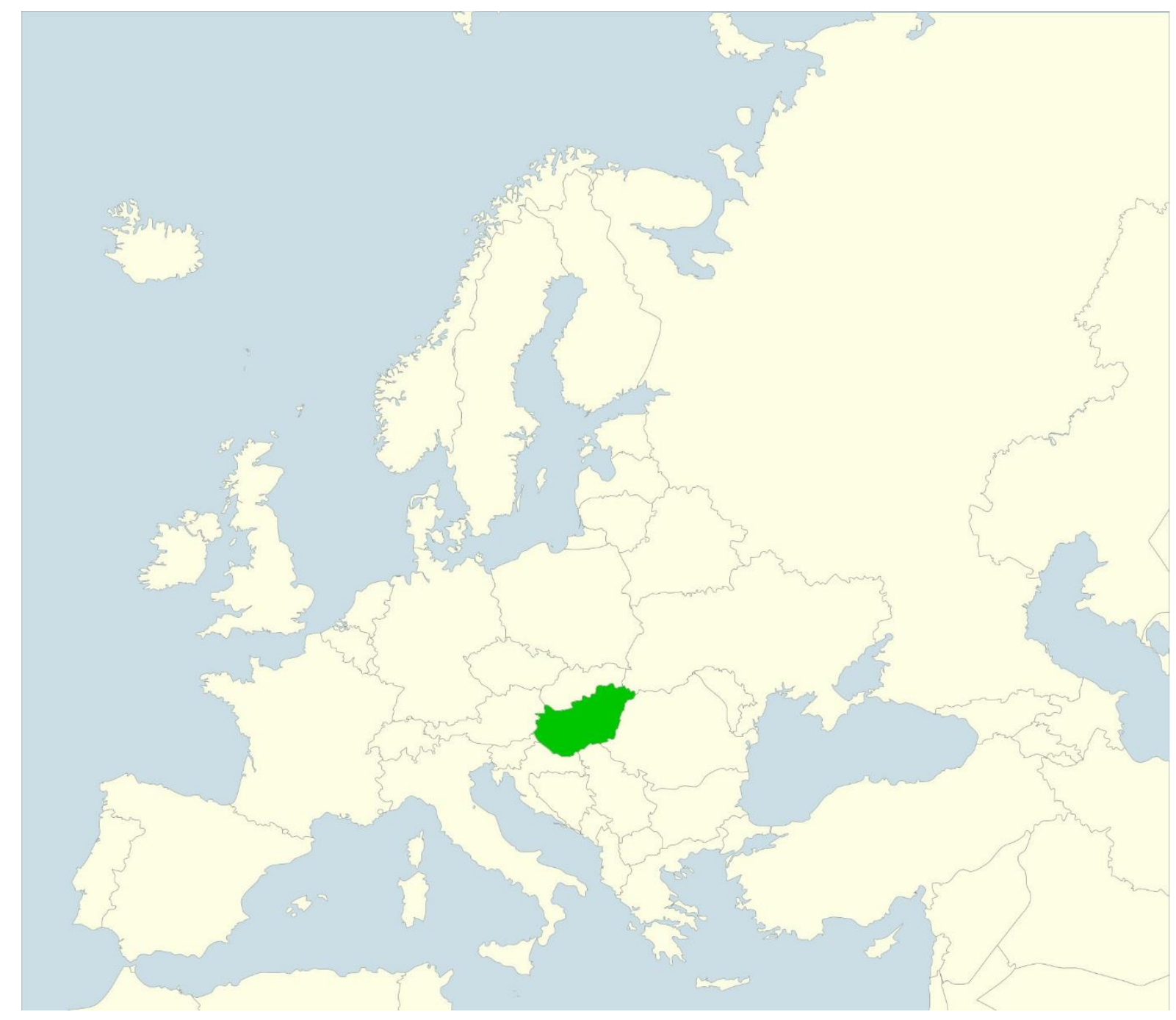

\footnotetext{
Bernadett Makkai - PhD student, University of Pécs, Doctoral School of Earth Sciences. Email: makkaib@gamma.ttk.pte.hu

2 Éva Máté PhD Student, University of Pécs, Doctoral School of Earth Sciences. Email: mate.eva911002@gmail.com ${ }^{3}$ Gábor Pirisi lecturer, University of Pécs, Institute of Geography, Department of Human Geography and Urban Studies. Email: pirisig@gamma.ttk.pte.hu

${ }^{4}$ András Trócsányi associate professor, head of department, University of Pécs, Institute of Geography, Department of Human Geography and Urban Studies, H-7624 Pécs, Ifjúság u. 6, Hungary. Email: troand@gamma.ttk.pte.hu
} 
Abstract: Due to the general demographic situation in Hungary and the recent overall crisis of this traditional settlement-type, Hungarian small towns have been facing an intensive shrinking since the last decade. Although natural decrease and migration loss are almost equal factors of population decline, outmigration seems to be a more strategic, critical problem for these settlements. There are hardly any reliable data available about the migrants leaving small towns, but some of them seem to support the wellknown assumption that the young people, who leave these towns are looking for wider horizons and better perspectives. The aim of the present paper is to analyse the outmigration of young adults from small towns, and give estimation about the international aspects of migration, which is hardly ever published in official statistics. The paper also aims at revealing the impact of the intensive migration on the local labour market. A short statistical analysis based on census data and two empirical surveys conducted by the authors are also included. One was carried out with the support of volunteer contributors, former small-town students, who tried to reconstruct the post-secondary school migration of their former classmates. The other survey contains a series of interviews focusing on the consequences of the young adults' migration on the labour market. The results facilitate the estimation regarding the (weak) capability of small towns to keep their young population, and highlight the problems of local developmental options within the context of demographic shrinkage.

Keywords: small towns, migration, shrinking, labour market

Absztrakt: Az általános magyarországi demográfiai helyzet és kisvárosok elhúzódó strukturális válsága miatt ez a hagyományos település az intenzív zsugorodásnak egyre jobban kitett térszín. Bár a természetes fogyás és a migrációs veszteség számszerüen hasonló mértéket ölt, ez utóbbi stratégiai jelentőségünek látszik a jövő szempontjából. Meglehetősen kevés pontos adat áll rendelkezésre a kisvárosokból elvándorlókról, azonban azok alátámasztják azokat a vélekedéseket, miszerint a távozók a több és jobb lehetöségért fordítanak hátat szülőföldjüknek. Jelen tanulmány célja, hogy kísérletet tegyen a kisvárosokból történő fiatal elvándorlás elemzésére, becsléseket adjon a folyamat számára és nemzetközi jellegére vonatkozóan, amellyel kapcsolatban mindeddig meglehetősen kevés információval rendelkezünk. Kísérletet teszünk az elvándorlás helyi munkaerőpiaci vonatkozásainak megismerésére is. A vizsgálat módszertanában népszámlálási statisztikai elemzésekkel indít, majd két empirikus felmérés eredményeit adja közre. A kisvárosi fiatal elvándorlás struktúrájának megismerésére önkéntesekkel végzett osztálykép-rekonstrukciót végeztünk, melynek keretében arra kértük a válaszadókat, hogy írják le, korábbi osztálytársaik - ismereteik szerint - hol és miből élnek jelenleg. A munkaerőpiaci hatások megismerésére több interjút készítettünk a kisvárosok dominálta térségben, ahol különböző szektorokban érintett munkáltatókat kérdeztünk a jelenség összetevőivel kapcsolatban. A vizsgálatok eredményei megerősítették, hogy a kisvárosoknak javarészt a megismert demográfiai változások miatt egyre kisebb népességmegtartó erejük van Magyarországon, ami a jelen gazdasági helyzeten túl a jövőbeni fejlődési pályákat is meghatározza.

Kulcsszavak: kisvárosok, migráció, zsugorodás, munkaerőpiac

\section{Introduction}

For centuries, small towns have possessed stable positions in the settlement network as market and service centres serving rural areas, and later as smaller industrial centres processing local goods and absorbing manpower. By the end of the $20^{\text {th }}$ century, the beginning of the $21^{\text {st }}$ century, these functions became questionable due to a number of reasons, including increased economic 
globalisation (Enyedi, 2012), more specifically the rearrangement and degradation of typical small town sectors (light and food industry) (Broadway, 2000; Molnár, 2013). There is also a decrease in service functions, leading to the decline of public services and institutions (Alston, 2004), in general, institutions financed from the central budget - for example, military bases, for example (Hannemann, 2003; Burdack, 2013).

In the politically transitioning countries of East-Central Europe, these processes were overlapped with post-socialist transformation, which, in several cases, had an amplifying effect on them. The transition and territorial policies enacted in these decades (or, partly the absence of these policies) revealed and increased the spatial disparities, more accurately, the peripherisation of non-metropolitan areas (Raagmaa, 2015).

It is probably not without reason that research interest in small towns is greater in the historically less urbanised Central and Eastern European region, as compared to Western Europe. With lower overall level of urbanisation and lack of non-capital metropolitan regions, small towns might play a slightly more important role, as suggested by some researchers (Slavík, 2002; Vaishar and Zapletalová, 2009; Kaczmarek and Konecka-Szydłowska, 2013), by assisting to close up the rural areas, or at least preventing to gain further "handicap". Accordingly, a certain type of role shifting or functional transformation of small towns is widely discussed, along with the question of how their long-term sustainability can be established (Vaishar and Greer-Wootten, 2006; Mayer and Knox, 2010; Vaishar, Zapletalová and Nováková, 2016). One of the most important elements of sustainability would be population retaining capacity, a feature, which has apparently become one of the most significant challenges for small towns (Fertner et al., 2015; Wirth et al., 2016). Accordingly, this issue is quite frequently discussed in East-Central Europe, a problematic region from a demographic point of view (Zuzańska-Żyśko, 2003; Kwiatek-Sołtys, 2006, 2015; Ježek, 2011; Kwiatek-Sołtys and Mainet, 2014).

Demographic decline is a characteristic symptom of the assumed important issues of small towns. Shrinking, however, is not a small-town specific problem, it is furthermore and primarily connected with declining industrial regions (Martinez-Fernandez et al., 2012; Pallagst, Wiechmann and Martinez-Fernandez, 2014; Haase et al., 2016). It is important to note that while shrinking is sometimes interpreted as an opportunity for restructuring and greening the urban space (Haase, 2008; Schilling and Logan, 2008) and therefore some narratives are dominated by the acceptance and even optimism (Hollander, 2010), as it acts as a trigger for some sort of problems (decreasing numbers of tax payers, employees and consumers, the process of infrastructure becoming outsized, the growing numbers of people demanding care, brown field problems, etc.) difficult to handle from local resources. Needless to say that small towns provide far less resources and possibilities to handle shrinking problem, there is simply no "land for retreat". If the decreasing number of pupils results in the closure of a secondary school in a city, the effect is only the narrowing variety of education, or growing travel time for the affected neighbourhood. In a small town, it could mean the loss of the one and only secondary school, resulting in a change in life quality and is a significant step backwards on the path of urbanisation.

Although there are only a limited number of papers focusing explicitly on the concept of shrinking in small towns (Troeger-Weiß and Domhardt, 2009; Leetmaa et al., 2015), there are many more with a focus on demographic problems of rural areas, districts, including small towns, as centres of these regions. Although an age-selective out-migration has always been a part of the "normal" life of small towns, especially when there was a large gap between the dynamism of rapidly industrialising urban areas and the not (yet) industrialised towns in the late $19^{\text {th }}$ century (Kolb, 2004). Later on, with the innovation of modernity it reached also the lower level of urban hierarchy, and migration became more balanced, even its direction changed parallel to the decay of large metropolitan regions in the 1970s, which created a certain optimism for the future of rural areas (Domina, 2006), or for the possible new roles of small towns (Elsasser, 1998). Still, the concept of rural restructuring (Woods, 2005) suggests that a consumption-oriented rurality providing high quality of life could be attractive enough to maintain some urban-to-rural migration and avoid the worst consequences of current demographic trends. Regions, like East-Central Europe with extended rural areas, low overall income levels and especially low earnings in rural regions can hardly be calculated with a dynamic counter-urbanisation in the near future. In these countries, including the Eastern part of Germany, different, but overlapping demographic challenges (natural 
decrease, short(er) life expectancy, regional and international out-migration) occur in small towns and their hinterlands of rural areas.

A relatively high number of research focuses on the age- and gender-selective out-migration from rural Europe. They highlight that outmigration of young people is both the reason and cause of peripherisation (Leibert, Montanari and Wiest, 2015), it is highly selective, not only by gender (Leibert, 2016), but of age as well and it leads to social erosion and to the perforation of social networks (Leibert and Wiest, 2016). Other authors underline that outmigration also endangers the quality of human capital by affecting the best-educated and best-motivated people to leave (Raagmaa, 2015), and by leaving, these areas have become more and more accepted or supported by the community and the family, even a kind of "culture of migration" could occur (Nugin, 2014; Leibert, 2016). Among other researchers, Christine Hannemann has underlined, based on empirical fieldwork in East-German small towns, that permanent outmigration of young people means a mid-term existential danger for small towns (Hannemann, 2003). The population of small towns is their most important, sometimes only resource, not simply because of its quantitative parameter, but also through the social capital expressed in relation systems, which is a typical small town phenomenon, arising from the (sometimes only presumptive) cohesion of the local society. Its crisis and later absence had strong reactions in an American interpretation (Putnam, 2001; Besser, Recker and Agnitsch, 2008; Besser, 2009), but European authors also mention the significance of related processes (Konecka-Szydłowska and Kaczmarek, 2010).

Hungarian small towns in the 1970s and 1980s were the beneficiaries of a regional administrational and public service system established on the theoretical foundations of the 'central spaces' concept (Pirisi and Trócsányi, 2015), which fact was reflected on both the qualitative and quantitative parameters of their urbanisation (Kovács, 2010). After the political transition, in spite of the polarisation in the Hungarian spatial structures and the overall decline of remote rural areas, the majority of typical small towns found themselves in relatively good condition by keeping some of their former economic and central functions, which resulted in a modest migration surplus they gained mostly from their hinterlands. The first decade of the new century proved their slow economic adaptation, and lack of investment and innovation did not help either, and finally, the withdrawal of state from rural areas (Pirisi and Trócsányi, 2015) resulted in a quite intensive outmigration from small towns. In the current study, the authors intend to present some data and information, as well as qualitative parameters about the age-selective outmigration affecting small towns. The research questions to be answered are the following:

a.) What is the estimated share of out-migrating people of one single cohort growing up in small towns?

b.) What are the typical targets of this out-migration? Do the majority of migrating youngsters move to regional centres, the capital region or even to foreign countries?

c.) What are the basic qualitative parameters of this migration? Is it a gender-selective and or qualification/education-selective issue?

d.) Are there any sensible effects of this outmigration on the local labour market? Does it have a positive or a negative impact?

\section{Methods}

According to the goals explained above, a complex methodological toolkit was used to fulfil the research. Selection of single methods was based on the different and well-known strengths and weaknesses of each element. Authors primarily aimed to build up an estimation about the youth outmigration. Qualitative tools were also used to complete the statistical analysis and estimation.

(1) The statistical analysis was based on official figures, from the published data of censuses held every ten years, which are available through the census web pages of the Hungarian Central Statistical Office (nepszamlalas.hu). For years in between, we used the regional statistical database of the Statistical Office, accessible in the TEIR system. Data were used to analyse the presence of cohorts of a 5-year span, comparing it to the number of people by their birth and to the later censuses. The difference between the two numbers 
(modified by the age-specific mortality values, although they are insignificant) accords to the net migration balance of the specific age group. The method is similar to the one used by Tim Leibert (Leibert, 2016) for defining the "population development" of certain German towns, although our method does not make a difference between the two sexes. As a consequence of the attributes of the data structure, it was not possible to provide a continuous developmental curve, but only to create snapshots in the years of censuses.

The statistical analysis targeted all Hungarian small towns, excluding the ones in the large metropolitan areas and urban agglomerations (mostly around Budapest) because of their completely different development path and character. According to our former studies, the definition of small towns for investigation was based on statistical and legal factors, thus including towns with less than 30,000 inhabitants and having the legal status of a town. Consequently, our quantitative analysis included 259 settlements among which the smallest ones had just over 1,000 inhabitants, while the largest ones had nearly 30,000 . The total population of small towns in this sense was 2.25 million in 2014 (about $23 \%$ of Hungary's total population), the average population size being 8,713 , and the median of the sample being 6,465.

(2) Secondly, we conducted an empirical survey to reveal quantitative and qualitative parameters of youth migration. With our empirical survey, we intend to overcome a specific problem. Although censuses theoretically provide detailed information about the demographic parameters of particular settlements, and it is even possible to collect data about people migrating there in a particular period of time, yet it is a problem to study the population of people who have left a certain settlement, as the census recorded them in some other place. Another methodological challenge is that due to the lack of official data, emigration to foreign countries is immeasurable from Hungarian statistics, yet this type of migration is gaining importance recently (Kapitány and Rohr, 2014). From the statistics of the recipient countries, virtually no information can be gathered relating to the Hungarian settlement level.

With a view to all this, we identified the target group of our research as the pool of young people who have completed their secondary education in small towns, and our main question was where these people lived 5-10 years after obtaining their secondary school leaving exams. How many of them stayed, and among those living elsewhere, how many have chosen to do so due to education and employment reasons? Although there are surveys from time to time looking at the causes of migration in small town youngsters, these tend to concentrate mostly on motivations, and have a qualitative approach (Alston, 2004). We, however, intended to establish a sample that allows us to estimate the rates of emigration affecting small towns. Our studies were performed with the inclusion of volunteers. All our contributors were asked to think back to their secondary school class, the one in which they completed their school leaving exam, and provide us with some basic information about their classmates. Besides their current place of residence we also wanted to know if they pursued higher education studies (if yes, where), and what their current occupation was. According to our current knowledge, there has not been any research in this field based on a similar method.

Our surveys have proven to be successful beyond expectations; through informal connections and social media calls, we managed to recruit a substantial number of cooperating volunteers. Eventually, 40 classes were included in the sample (36 in small towns and four in other cities as control), representing 36 different education institutions and 23 small towns. This altogether yielded 902 individual records (of which 813 were from small towns). The years of the school leaving exams ranged between 2001-2013, the classes in the sample having had their leaving exams 8.5 years back as an average (reference: spring 2016).

Sampling was intentionally focused on graduating secondary school students, thus it was certainly not representative. As a result of such a selection, certain groups were left out from the survey, but the authors did intentionally focus on the intellectuals of future generations, on the re-creation or absence of intellectual and social capital. We assume 
that the migration behaviour of people without secondary school certificates may differ from what we are going to present in the present paper, yet there was no significant difference ${ }^{5}$ between data from the two secondary school types ${ }^{6}$ involved in research (grammar school and vocational secondary school) that end with school leaving exam certificates. Therefore, we later did not handle these two types separately.

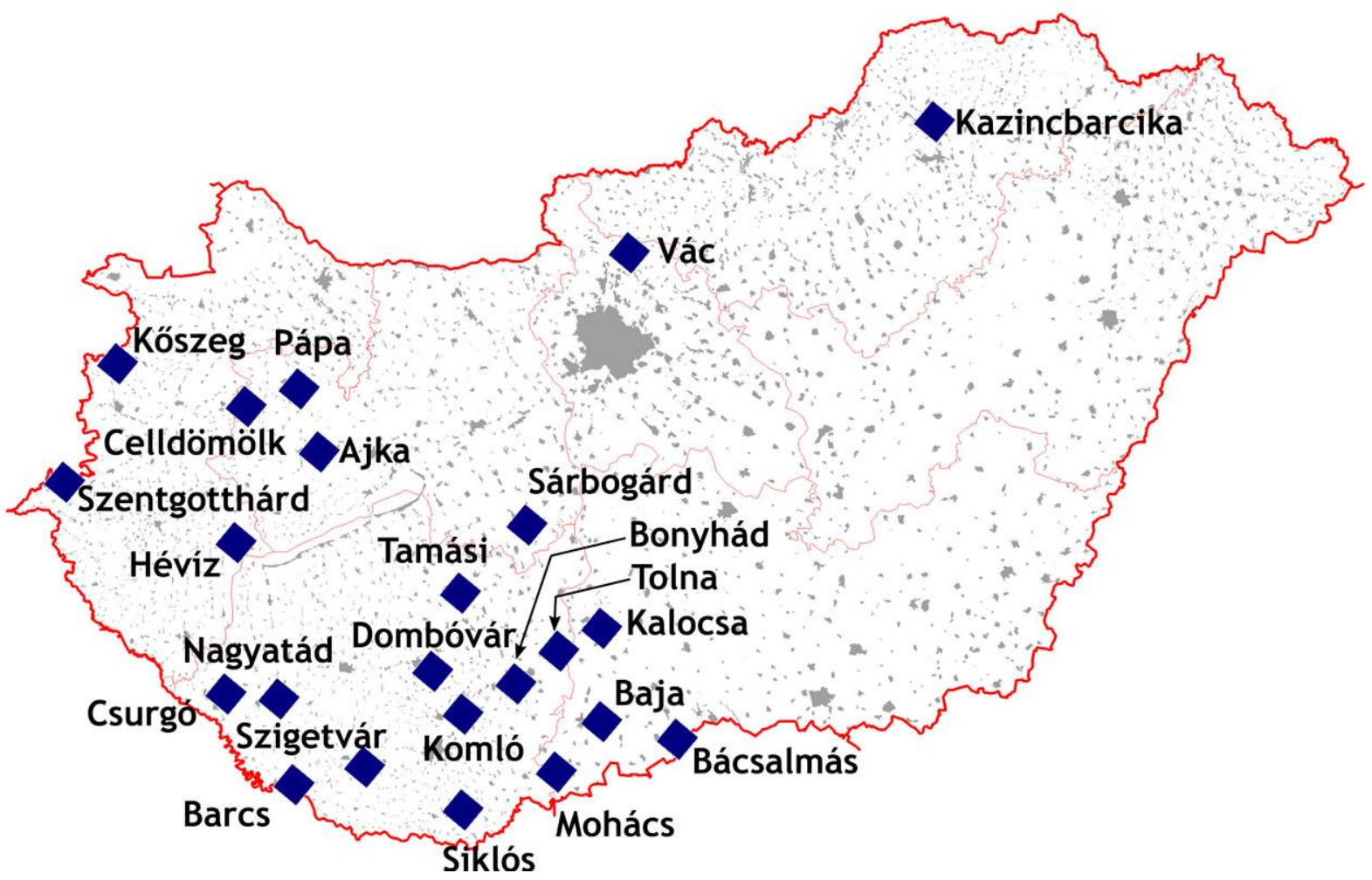

Fig 1. The location of small towns included in the survey. Source: edited by the authors

The sample was not representative in geographical terms either, as the network of our contributor volunteers covered mostly the western part of the country, yielding our sample from small towns of that particular region (Fig. 1). Nevertheless, the studied town category is quite a complex one regarding its size, genetic and functional types, thus representing properly the pool of Hungarian small towns. From a geographic aspect, too, the differences were quite modest within the pool of towns, even though there is a great deal of dissimilarity in the welfare indicators of towns in the northwest and the southwest of Hungary. Selected small towns are mainly truly "typical" small towns - relying on Pál Beluszky's typology (Beluszky, 1999), because these traditional small towns, often with district centre functions, are the ones that have secondary schools (Trócsányi, Pirisi and Makkai, 2014). Not surprisingly, the average population size of the 23 small towns included in the study exceeded 14 thousand.

(3) We completed our analyses with a case study, surveying the employers' side of the labour market in four small towns of a disadvantaged rural region. We sought answer to the question how sensitively employers react to intensive outmigration, how much and how they are affected by the shrinkage and depletion of the labour market. Looking at these issues, we held interviews with characteristic employers of the rural region we had selected along particular guidelines, and evaluated the results qualitatively.

\footnotetext{
${ }^{5}$ Authors found only a modest difference of $1-3 \%$ in each main question between the respondents representing the two surveyed school types.

6 Vocational secondary schools in Hungary give single profession oriented training, with slightly limited general knowledge. Students in both types generally pass the very same secondary school leaving exam, which gives them the requisite for tertiary education.
} 
First, we determined the sampling area, trying to define a region, which is greatly influenced by settlement structure and the location within the country/region/county, where the regional importance of small towns is considerable; moreover, they enjoy exclusivity in supplying their attraction zone. Along the above lines, we decided to choose the Baranyai-hegyhát region (Fig. 2), a typical Hungarian rural area whose everyday life is formed and dominated by the small towns situated inside it: Dombóvár, Komló, Sásd and Mágocs (in the order of decreasing size). We had samples in our empirical survey (see Fig. 1 as well) from the first two small towns. The other two are practically too small to have secondary schools, and therefore local children usually choose secondary schools in the first two mentioned above. Among our sets of individual records, we received answers from people coming from Sásd and Mágocs, but in low numbers. Also, the Hegyhát area represents a typical Hungarian rural space, in which the role of small towns should be crucial, however the majority of them experience shrinking.

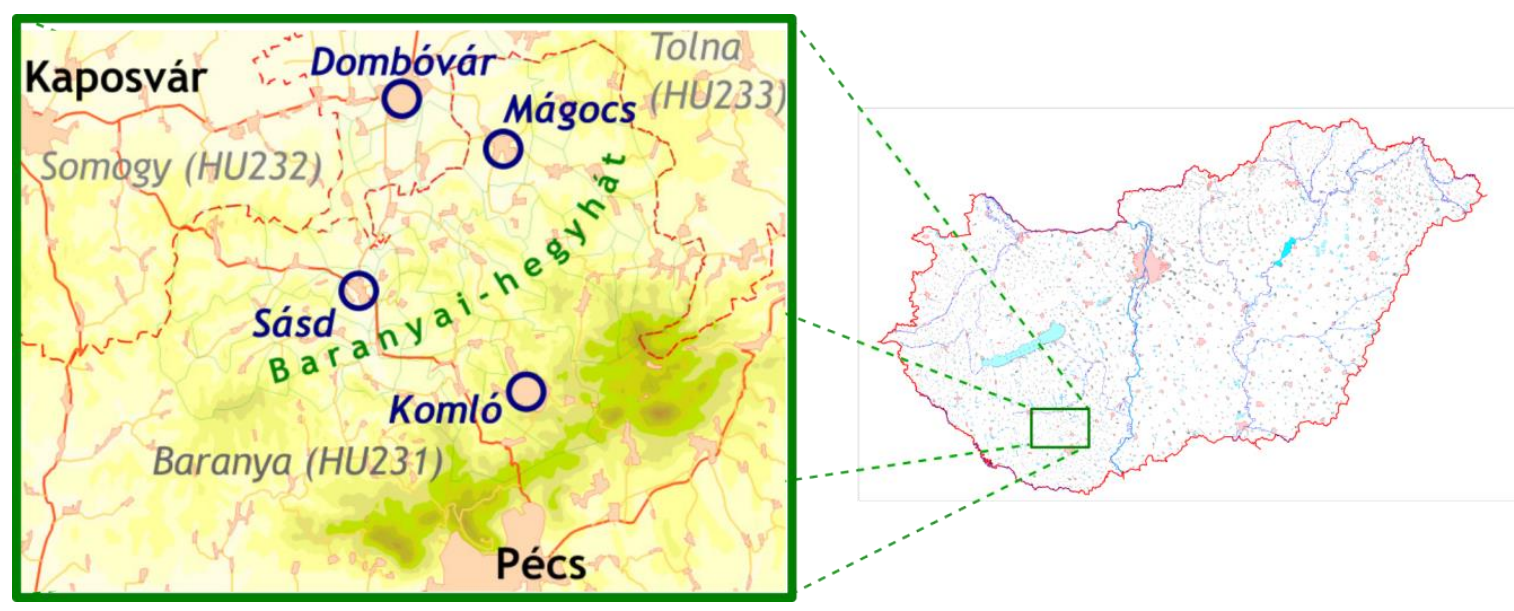

Fig 2. Locations of the interviews. Source: edited by the authors

These four small towns have evolved along completely different routes: Komló, the largest one (with a population of 23 thousand in 2015) is a dramatically shrinking town, once a socialist coalmining colony. Dombóvár $(18,461)$ is an industrialised town with some regional roles and an important railway junction. Sásd $(3,053)$ is an under-developed district centre, and Mágocs $(2,316)$ is a predominantly agricultural settlement, which won the town title only in 2009. Samples from both Dombóvár and Komló were included in our empirical survey shown above, allowing for comparisons thereof.

The in-depth interviews were mildly/intermediately structured ones that could be divided into three larger units or subjects: the first series of questions inquired about the type of the enterprise, the second block included questions about its current employees, while the third group looked at the position of the enterprise in the labour market of the region. We tried to select a high variety of different enterprises to be approached, so that every locally existing branch of economy is covered, hopefully providing us with a result that can characterise regional demand for jobs (telling us if trained or less qualified manpower is sought after, what the age-structure of groups with various qualifications is, etc.). Two interviews were held in each of the four small towns, and the list of enterprises is shown in Table 1, enlisting their names, seats and company profiles. 
Tab 1. Interviewees included in our sample. Source: edited by the authors, based on own survey

\begin{tabular}{|l|c|l|c|}
\hline Name of enterprise & Location & \multicolumn{1}{|c|}{ Branch } & Number of staff \\
\hline Rutin Ltd. & Dombóvár & $\begin{array}{l}\text { Industrial - metal and steel } \\
\text { processing }\end{array}$ & 350 \\
\hline $\begin{array}{l}\text { The Best Reklám } \\
\text { Hungary Ltd. }\end{array}$ & Dombóvár & $\begin{array}{l}\text { Service - designing marketing } \\
\text { and promotional printed material }\end{array}$ & 25 \\
\hline Uni-System Bau Ltd. & Komló & $\begin{array}{l}\text { Industrial - metal and steel } \\
\text { processing }\end{array}$ & 140 \\
\hline Echo-Sprint Ltd. & Komló & $\begin{array}{l}\text { Service - selling energy saving } \\
\text { lights, lubricants and fuels }\end{array}$ & 9 \\
\hline Szabó Tüzép & Sásd & $\begin{array}{l}\text { Service - trading in building raw } \\
\text { materials }\end{array}$ & 5 \\
\hline HEG Ltd. & Sásd & Industrial - metal processing & 16 \\
\hline SHS Ltd. & Mágocs & $\begin{array}{l}\text { Service - accounting and } \\
\text { financial services }\end{array}$ & 27 \\
\hline Makrom Ltd. & Mágocs & $\begin{array}{l}\text { Agriculture - animal farming and } \\
\text { milk production }\end{array}$ & 10 \\
\hline
\end{tabular}

\section{Statistical estimation of young age outmigration}

The shrinkage of small towns is, of course, not a new phenomenon. Certain types of small towns, especially agricultural towns of the Hungarian Great Plain region, have had decreasing populations since the dawn of the $20^{\text {th }}$ century. However, as we have mentioned in the Introduction, the last third of the $20^{\text {th }}$ century, especially the 1970 s and 1980 s brought about the golden age of small towns in a demographic sense. This period was characterised by an altogether positive demographic trend and an increase in small towns' functional and demographic importance. Moreover, even as late as in the 1990s - when natural population decline started to become more and more intense and the populations of cities were reduced by intensive suburbanisation, small towns were able to produce a slightly positive migration balance (Pirisi and Trócsányi, 2015).

This situation changed fundamentally at the turn of the century: the comparison of the 2001 and 2011 censuses indicated a substantial shrinkage. About $4 / 5$ of all of the small towns investigated suffered population decline during this period: in $62 \%$ of the cases every $20^{\text {th }}$, and in $27 \%$ of the cases at least every $10^{\text {th }}$ citizen was lost. The population reduction of four settlements exceeded $15 \%$, in a situation when the country had left the worst years of the transition and shock therapy behind, and economic growth between 2001-2006 reached 3.5-4\% (but then concluding to a $-6.6 \%$ crisis in 2009). The data about the small towns' shrinking needs to be compared to the national average: a natural decrease of $-3.8 \%$ and a positive (!) international migration balance of $1.2 \%$ means only a loss of $-2.6 \%$ of Hungary's population between 2001 and 2011 , while small towns lost $5.3 \%$ of their inhabitants of 2001. At first sight, this decline seems to be caused by natural loss. Only about $24 \%$ of the total population change in small towns between 2001 and 2011 is due directly to migration. Migration balance between 2001-2007 decreased gradually year by year, reaching an annual $-5.0 \%$ by 2007 , which was later counterbalanced somewhat. We have no useful information published about the population affected by migration. The statistical analyses by Zsolt Németh, relying on an immense database regarding the 2001 census, concluded the following about the 1990-2001 period: people migrating from small towns towards Budapest, larger towns and cities were mostly of higher social status than the local average, substituted by citizens of lower social status - mostly from villages (Németh, 2011). For us, the most fascinating result to find out was the age composition of outmigrating people, for which we used a simple estimation method (Pirisi, 2014). From the 2011 census data (and, for a comparison, the 2001 data), the population sizes of particular age groups were compared with the number of births corresponding to that particular age group, i.e. for example the pool of people aged between 0-4 in 2011 with the number of those born between 2007-2011. The number of 
births was corrected with the age-specific national average mortality value, thus the difference between the two values could result only from net migration.

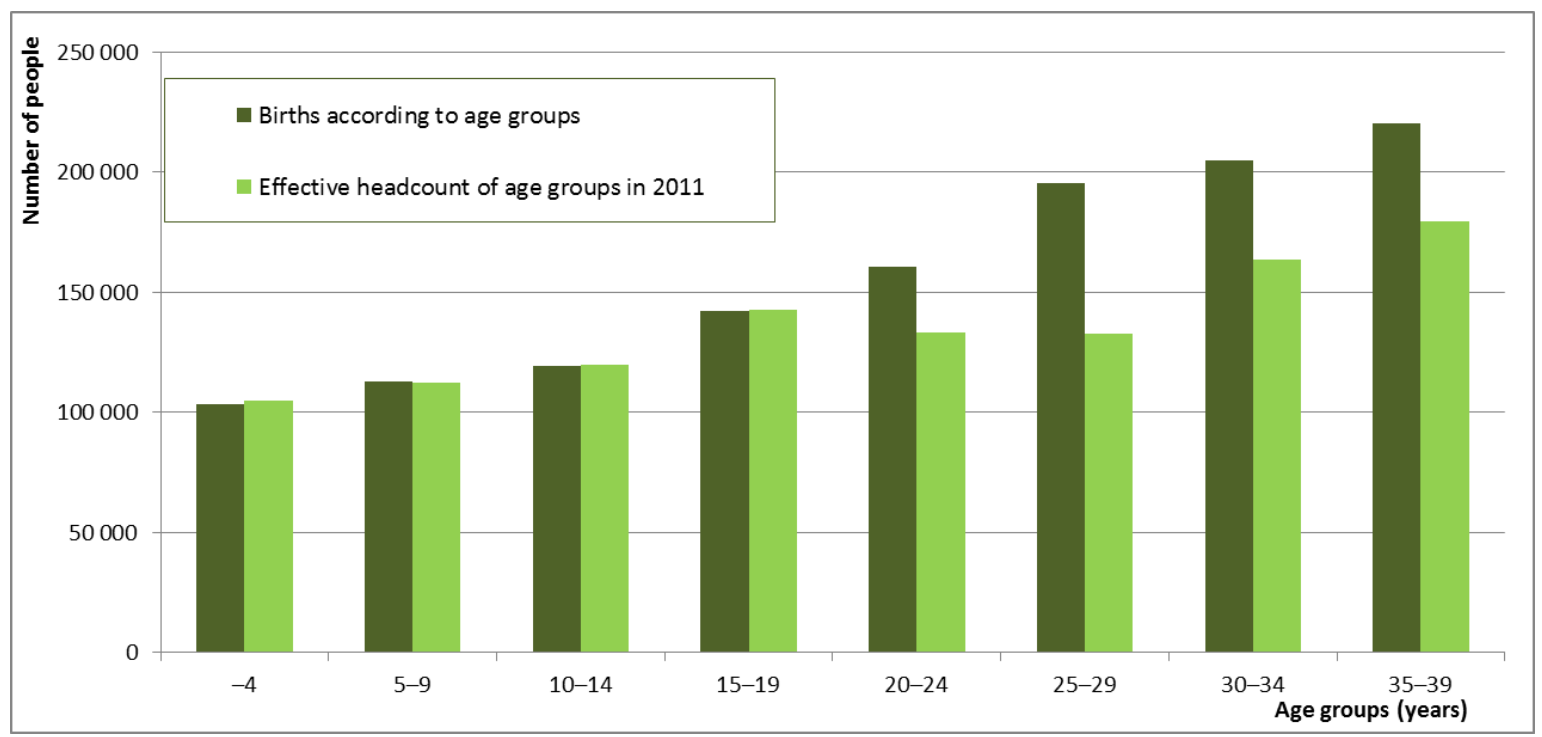

Fig 3. Number of citizens actually present in various age-groups of small towns and the numbers anticipated based on the number of births in the same cohorts (2011). Source: edited by the authors, based on the official census data of the Hungarian Central Statistical Office

As suggested by Fig. 3, small towns are able to retain their populations in the lower age groups, actually meaning that families having settled here and having children typically do not move away (or their migration balance is stable). The dramatic change occurs in the age group of the twenties. The net migration loss in the age group of 20-24 years is 17\%, and that of people aged 25-29 is $31.5 \%$, calculated on the basis of the corresponding number of births. Instead of instantly coming up with the answer that this reflects the higher education participation rates of people with secondary school certificates, we want to emphasise that in Hungary, people entering higher education almost never re-register their place of residence to the university town once admitted, thus, these people statistically continue to be residents of small towns. Similarly, people taking up a job abroad regularly or for longer periods without re-registering at their place of work are not included in the missing parts. Their exact number in 2011 is unknown; according to statistics, 21,000 small town residents worked in foreign locations (with unknown age distribution), but from our experience it is assumed that this figure is only the tip of the iceberg. It is also important to note that working abroad became really popular after 2011. The "deficit" decreases in the age groups above 30 , which might imply that being away is only temporary in the case of young people, or, more realistically, that outmigration has become more intense in the past decade.

In order to confirm or reject the latter assumption, the 2001 census data were analysed too, using the same method as described above. The percentage differences in each age group were shown for the 2001 and 2011 censuses (Fig. 4).

The difference is considerable, well signifying the transformations in recent decade(s). The missing number of people in the two critical age groups of 20-24 and 25-29 in 2011 is about twice as many as in $2001: 7.7 \%$ and $15.5 \%$, respectively. Another spectacular difference is that the positive immigration balance of the 1990s possibly shows up in young families, since the substantial positive difference in the age groups below 14 years is most likely caused by the immigration of families with small children. 


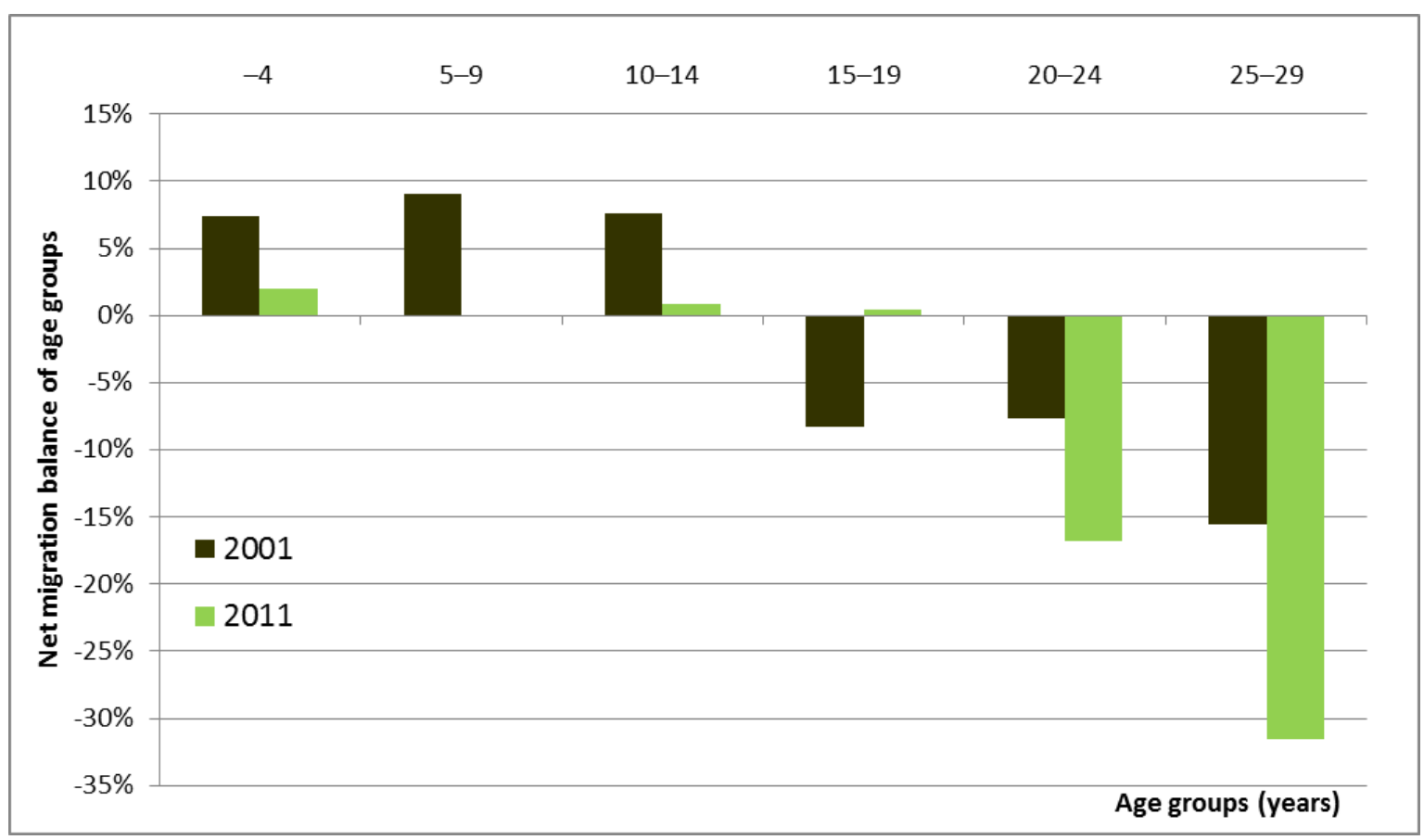

Fig 4. Net migration balance of the different age groups since the last census in small towns (2001, 2011). Source: edited by the authors, based on the official census data of the Hungarian Central Statistical Office

The outmigration problem shown above is of course not independent from the geographic location of small towns (Fig. 5). The west-to-east sloping gradient normally observed in Hungary, and the effect of distance from the capital can both be seen in the spatial structure. Small towns with positive values are not to be found among the few settlements possessing higher education institutions, but instead, along the boundaries of agglomerations, benefiting from the positive effects of big cities, or further away in the country, being well-known tourism resort places with spas. Among the settlements belonging to the lowermost category with the highest (more than $30 \%$ ) deficit there are a few in the western part of the country too, but the highest spatial concentration of such settlements is highest in the east: both in the north-eastern border region and in the middle of the Great Plain, among the agricultural towns that have long been declining historically, demographically, and also in a social sense.

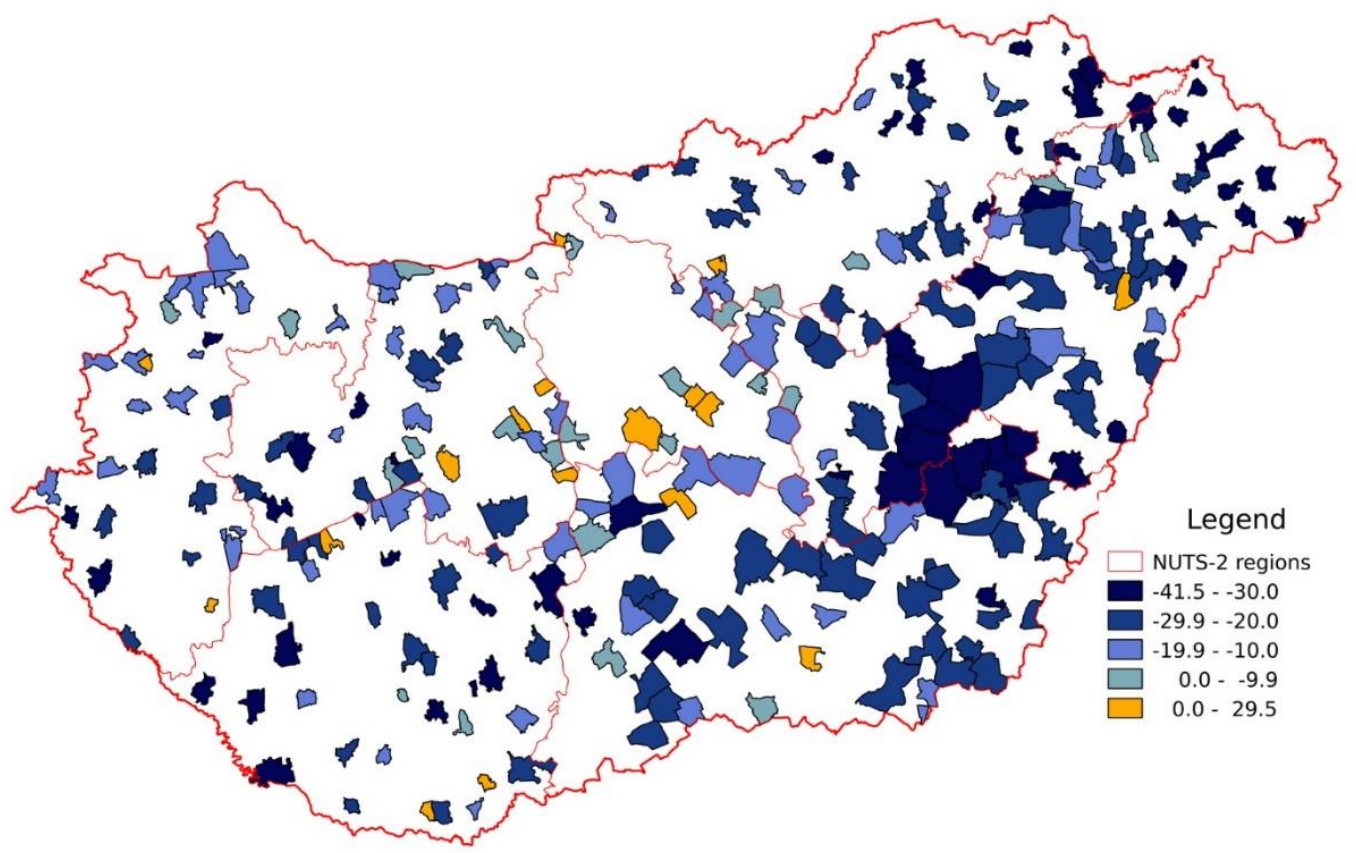

Fig 5. Percentage of missing population aged 20-29, relative to corresponding births in Hungarian small towns. Source: edited by the authors, based on the official census data of the Hungarian Central Statistical Office 
However, the studied phenomenon was found to be less dependent on other, non-geographic parameters, than expected (Table 2.). Outmigration of young people was the most intensive, not from the smallest, functionally weakest settlements, but from the largest ones in the studied region, which are practically the strongest, traditionally urban small towns. Correlation with developmental level was found to be much weaker than expected - the latter was expressed by categorising in a complex indicator system widely used in Hungarian settlement planning (Faluvégi and Tipold, 2007).

Tab 2. The share of age groups 20-24 and 25-29 compared to the number of corresponding live births in different small town categories (2011). Source: calculated and edited by the authors, based on the public database and census data of the Hungarian Central Statistical Office

\begin{tabular}{|c|c|c|c|c|c|c|c|}
\hline \multirow{3}{*}{\multicolumn{2}{|c|}{ Category }} & \multicolumn{2}{|c|}{$\begin{array}{l}\text { Calculated } \\
\text { deficit (\%) }\end{array}$} & \multirow{3}{*}{\multicolumn{2}{|c|}{ Category }} & \multicolumn{2}{|c|}{$\begin{array}{c}\text { Calculated deficit } \\
(\%)\end{array}$} \\
\hline & & $20-24$ & $25-29$ & & & $20-24$ & $25-29$ \\
\hline & & \multicolumn{2}{|c|}{ years } & & & \multicolumn{2}{|c|}{ years } \\
\hline \multirow{5}{*}{ 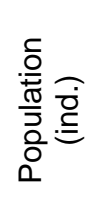 } & below 5,000 & -11.2 & -29.8 & \multirow{5}{*}{$\begin{array}{l}\text { Complex developmental } \\
\text { level category of LAU2 } \\
\text { regions of the small } \\
\text { towns (quintiles) }\end{array}$} & lower & -23.9 & -32.0 \\
\hline & $5-10,000$ & -12.7 & -26.0 & & lower-middle & -14.4 & -30.6 \\
\hline & $10-15,000$ & -14.5 & -26.6 & & middle & -12.1 & -30.8 \\
\hline & $15-20,000$ & -20.5 & -31.6 & & upper-middle & -13.0 & -30.6 \\
\hline & $20-30,000$ & -13.2 & -34.0 & & upper & -13.0 & -30.1 \\
\hline
\end{tabular}

Altogether, as statistical data suggest, $20 \%$ of young people born in small towns are not found in the same town at their age of 30 . This loss does apparently affect the human resources of the small towns, the only question being how realistic this rate is (especially with regard to the aforementioned uncertainties of migration statistics). In our empirical survey shown below we sought an answer not only to the question of how accurate this finding can be (the methodology has limited suitability for this), but also tried to find out where young people from small towns tend to migrate.

\section{Results of the empirical survey}

The focal question in our survey was how many of the young people having passed their secondary school leaving exams stay and how many choose a different place of residence. As a consequence of the indirect method of the survey (there were 40 volunteers who provided data about 900 former schoolmates), our knowledge about the demographic composition of the people surveyed is limited. Our sampling was done with an average of 8.5 years after the secondary school leaving exams, meaning an average of 26.8 years in age. There were 368 male and 534 female "records", which resulted a ratio of $40 \%$ from men's point of view. Tertiary education enrolment is quite high, bachelor or master degrees were reported (45.6\%)in 412 cases and in further 20 cases $(2.2 \%)$ higher education studies have not been finished yet (a surprisingly low number). This means, that the great majority of our sample entered the labour market even if they had not completed their higher education studies in the meantime. It is important to note that people obtaining their secondary school certificate are not the same who actually live in the particular small towns: only 59\% of all the young people surveyed (altogether 813 individuals) were actually small town residents, all the rest lived mostly in the villages of the attraction zones at the time of passing their secondary school leaving exams. We have no data regarding the number of people who went to secondary schools of larger towns and county capitals, but it can be assumed that outmigration among these people is at least as common as in our sample.

The first, most important and most shocking result was that only about $38 \%$ of people having passed their school leaving exams as residents of particular small towns were found by our survey to be staying in the same place. This value is much higher (about twice as high) as the results of the statistical estimation. Due to the special methodology of the investigation we cannot state that the obtained figures are true for each and every small town, yet it is considerable that only few such settlements were included in the sample that were classified in the lower most statistical category, i.e. the one influenced the most by the effects of migration. Accordingly, our results are 
possibly not to be generalised, but it can be established that the outmigration of young people does exceed the figures calculated earlier (Table 3.).

Tab 3. Current places of residence of people having taken their secondary school leaving exam in small towns. Source: calculated by the authors, based on their empirical survey

\begin{tabular}{|l|c|c|}
\hline \multicolumn{3}{|c|}{ People having taken their secondary school leaving exam in a small town } \\
\hline Current place of residence: & $\begin{array}{c}\text { small town resident at the time of } \\
\text { the school leaving exam (100\%) }\end{array}$ & $\begin{array}{c}\text { not a small town } \\
\text { resident (100\%) }\end{array}$ \\
\hline $\begin{array}{l}\text { small town where the school leaving } \\
\text { exam was taken }\end{array}$ & $38.1 \%$ & $5.6 \%$ \\
\hline other small town & $7.5 \%$ & $10.4 \%$ \\
\hline village & $2.3 \%$ & $32.9 \%$ \\
\hline city & $16.6 \%$ & $21.9 \%$ \\
\hline Budapest & $20.5 \%$ & $18.6 \%$ \\
\hline abroad & $15.0 \%$ & $10.6 \%$ \\
\hline
\end{tabular}

Not surprisingly, people migrating away do not normally choose another small town or village (among the latter, the proportion of married people is high, meaning that family reasons could account for such a decision). The extremely high rate of Budapest can be surprising, but moving abroad is less common than expected ${ }^{7}$. However, this, too, is relative: if the $15 \%$ rate in our sample is projected to the age group of people in their twenties, nearly 40 thousand people would be working abroad, only from small towns. If small towns are considered to be typical in this respect, the number of people of this age group trying to make a living abroad would amount to 160,000 in the country ${ }^{8}$, which, on the other hand, complies well with the estimations regarding total working abroad figures in Hungary (Blaskó and Gödri, 2014; Kapitány and Rohr, 2014; Gödri, 2015).

Differences between the sexes are quite low. Women (represented at a rate of $62 \%$ in our sample, due to school selectivity) are slightly more likely to stay in their home town (with a possibility of $27 \%$ by female, $21 \%$ by male respondents), but at the same time, their rate of emigration abroad is somewhat higher than that of men (difference of $14 \%$ to $11 \%$ ). Young men, however, are a bit more likely to move to the capital ( $24 \%$ over $18 \%)$.

The sample of non-small town residents is pretty similar, with only the proportion of those with foreign residence being lower and those with city residence being higher than what was formerly analysed. What is relevant for us is that only $5.6 \%$ settled in the small town in which they once had gone to school. This suggests that small towns appear less attractive even from villages; urbanisation-related migration nowadays overleaps small towns, leading directly towards cities.

Although there are considerable differences between the average values of various surveyed towns, the varieties of the answers in different towns includes rates for "staying in small town" from 0 (!) to $36 \%$, for "living abroad" from 0 to $44 \%$. These cannot be simply correlated with the basic features of spatial structure. Although there is no considerable difference between the two basic school types (secondary grammar school and vocational school), yet their branches, specialities and different qualities can be distinguishing factors, besides the small towns themselves. The spectrum is pretty broad: there were classes in which the rate of people staying in the small town was as low as just $10 \%$, yet the average values of towns in the northwest

\footnotetext{
${ }^{7}$ Our expectations about migration abroad were intensified by the fact that our collaborating volunteers had told us things like "every other person they know work in London". It seems that the way the situation is perceived is more dramatic than the situation itself.

8 It is difficult to estimate how many migrants leave Hungary; the Hungarian Central Statistical Office makes estimations mostly on the basis of the recipient countries' mirror statistics. It is not clearly defined either who can be regarded as a migrant settling down permanently in a foreign country, or who are those who only work abroad for an extended period (but will potentially return home). The subjects of our research usually fall into the latter category; their number is estimated to be around (at least) 350,000 individuals by the sources referred to above.
} 
vs. the southwest (where towns traditionally differ in their economic status) were almost identical. Where there were differences, these were due to local or probably institutional causes.

It is sure that higher education plays a role in dragging young people away. Due to the peculiarity of the sampling, the proportion of young people participating or having graduated in higher education was quite high, reaching $60 \%$, which is due to the selectivity of the sample for certain school types. It is nevertheless apparent that only $28 \%$ of young people entering higher education will stay later on, whereas this rate in the case of youngsters not continuing their studies after secondary school is $48 \%$. Thus, the increasing rate of young people participating in higher education is another factor acting against the survival of small towns, by opening routes of mobility for youngsters, in which the towns providing their secondary education certificates can play only subordinate roles.

The rates of people leaving small towns are not greater in cases when longer time passes after the school leaving exam. This suggests that the decisions about setting off are made relatively early (most certainly when entering higher education, but apparently in the cases of taking up a job, too), and there are some signs suggesting an increasing rate of outmigration (this is why the number of people leaving is not greater in older samples).

Although the lack of job opportunities is generally thought to be among the primary reasons why people migrate away, our data add some detail to such reasoning. The employment status of young people living in small towns included in our survey is definitely favourable. At the time of the survey, an average of $68 \%$ of them had a full-time job, $13 \%$ pursued their higher education studies, $17 \%$ (all of them women) were on maternity leave, and the rate of unemployed people only slightly exceeded $2 \%{ }^{9}$ (unemployment rate in Hungary in the studied period being almost $5 \%$ ).

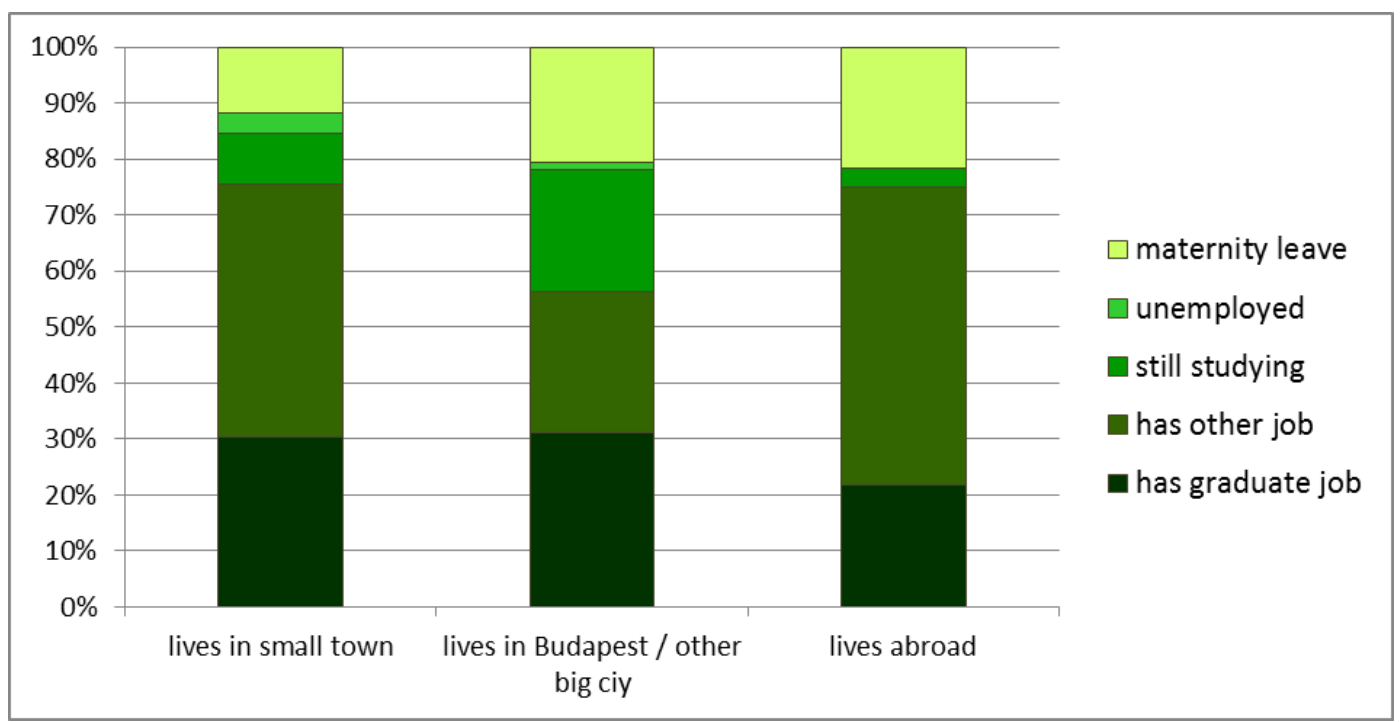

Fig 6. The situation of the surveyed small-town (-born) young people in the labour market. Source: edited by the authors, based on their empirical survey

As Fig. 6 suggests, there are some differences or dissimilarities regarding the above distribution, but only some of them are remarkable. One of the most important features is that although small towns absorb quite many degree holder employees, yet nearly $35 \%$ of all degree holders of these settlements work in positions that would otherwise not need higher education qualifications (the same figures in Hungarian cities and Budapest are $22 \%$ and $20 \%$, respectively, and about $34 \%$ abroad). It is also notable that when young people establish a family, this is not associated with small towns any longer, at least the rate of current full-time mothers is higher in Hungarian

\footnotetext{
${ }^{9}$ At this point, once again we suppose that the survey might be deceiving. Probably, not everyone of our collaborating volunteers were able to accurately recall their classes, including each and every classmate, but instead it can be assumed that they more easily overlooked some of their mates who had problems in their lives, were permanently without a job and have thus gave up their social contacts.
} 
large towns and abroad than in small towns. Unemployment is the greatest among those staying, even if this figure is not substantial (reaching only $3.5 \%$ ).

Altogether, the outmigration of young people with secondary school certificates from small towns seems to be almost desperate. Most certainly, there are a number of motifs contributing to outmigration, but neither the commencement of higher education studies, nor the choice of job opportunities can account for this on their own right. High employment rate for those staying suggests that this type of outmigration has brought about dramatic transformation to the labour market of small towns and their attraction zones, in which massive surplus was observed for years.

\section{General conclusions from the interview results: the other side of outmigration}

Experience from interviews conducted in small towns was in accordance with the formerly surveyed migration attitudes: the demand side of the labour market is clearly influenced by the negative effects of outmigration by young residents. Although the profile of enterprises, their staff composition and the target group for staff recruitment were different, the answers turned out to be surprisingly similar.

As we explained in the methodological chapter, the interviews had three main focus points: the reactions and status of the enterprise, the quality and circumstances of employed and finally, the values and issues of local labour force. According to these questions, we analysed the interviews in a three-fold approach. The general experiences gained by the interviews and organized in three groups according to the focus of the research were summarized in Table 4.

The interviewees generally claimed that the research area we had chosen is an ageing, shrinking periphery - also according to their interpretation. Surprisingly, they expressed the very same attitude, although not being in an everyday contact or knowing each other. Moreover, slightly all of them explained that there is accessible labour force in the Baranyai-hegyhát region, but they cannot employ them due to the lack of proper education. "The qualified have already left and those, who had a vocation and were good at it, left the country, or at least, Baranya county." said the interviewee of HEG Lp., Sásd. This idea occurred at the others too, combined with the issue of the ageing employees: "Some have been working here for 30 years, they know this place better than I do. In a few years, they are getting retired, what am I supposed to do then?"Szabó Tüzép, Sásd.

According to the interviewed, the local labour supply causes emerging problems for small town enterprises. Most of the employed are commuters, which gives a temporary solution for these issues, although some extreme cases have also occurred, which could mean that the labour supplies of the micro region are diminishing. "We even have workers from Szabolcs-SzatmárBereg county, because the local workers, who live close to Dombóvár, are working abroad, especially those, who have language skills. We have no other chance, and those, who are coming from East-Hungary, have no better either." - Rutin Lp., Dombóvár.

The quality of young workers (according to our interviewees) is getting weaker year by year. This means that not only the education and their skills are poor or inappropriate, but the attitude, the motivation and at least their willingness to work have disappeared. The expression or the description of "generation $Y$ " was quite common in the interviews, defining an irresponsible working behaviour with it. "Sometimes they cannot handle the machines, although they learnt it in school, but they pay no attention. They don't care, even for their own safety. We don't want to employ such people." - Uni-System Bau Ltd. On the other hand, the opportunities and average incomes of these small towns are way under the national average, which, we assume, destroys the motivation of young qualified people.

The local organisational level of the labour market is not very favourable anyway. Our interviewees complained about the lack of manpower-supply channels, such as an effective recruitment network that would assist employers to find and admit new members of staff. Answers to the question "Do you encounter competition between companies with similar profiles for manpower?" depended mostly on the portfolio and staff composition of the particular company, 
but it appears that companies employing higher number of individuals do face competition more and more often. Such a competition though, does not necessarily appear among the four studied small towns, but instead, they are the county seats, Budapest and foreign competitors that have greater attraction potential. In most of the cases, this does not actually mean higher incomes, but a different life standard and opportunities - as employees understand this.

Tab 4. Logical nodes of conclusions from the interviews. Source: edited by Máté, É.

\begin{tabular}{|c|c|c|c|c|}
\hline & Problem & Reaction & Effect & Example from interviews \\
\hline \multirow{2}{*}{$\begin{array}{l}0 \\
\frac{0}{0} \\
\frac{0}{2} \\
\frac{2}{0} \\
0 \\
\frac{1}{E}\end{array}$} & $\begin{array}{l}\text { Long term } \\
\text { workers with low } \\
\text { salaries }\end{array}$ & $\begin{array}{l}\text { Bitter, } \\
\text { disenchanted } \\
\text { attitude }\end{array}$ & $\begin{array}{l}\text { Motivating their } \\
\text { children to move to } \\
\text { bigger cities or abroad }\end{array}$ & $\begin{array}{l}\text { A local accountant opened an } \\
\text { office in the nearest city, so } \\
\text { her children can later move } \\
\text { there, take over and relocate } \\
\text { the business }\end{array}$ \\
\hline & $\begin{array}{l}\text { Missing practical } \\
\text { skills of newly } \\
\text { employed }\end{array}$ & $\begin{array}{l}\text { Conflicts with } \\
\text { the employer } \\
\text { and old } \\
\text { employees }\end{array}$ & $\begin{array}{l}\text { Changing jobs } \\
\text { frequently, losing } \\
\text { motivation }\end{array}$ & $\begin{array}{l}\text { Almost all interviewees } \\
\text { complained about generation } \\
\text { Y and their irresponsibility at } \\
\text { work }\end{array}$ \\
\hline \multirow{2}{*}{ 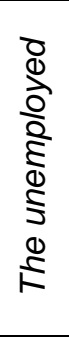 } & $\begin{array}{l}\text { Lack of high } \\
\text { prestige } \\
\text { workplaces }\end{array}$ & $\begin{array}{l}\text { Qualified } \\
\text { people are } \\
\text { leaving }\end{array}$ & Ageing local society & $\begin{array}{l}\text { Entrepreneurs claimed that } \\
\text { they would not force their } \\
\text { children to stay because they } \\
\text { cannot offer better } \\
\text { opportunities }\end{array}$ \\
\hline & $\begin{array}{l}\text { Low standard } \\
\text { working } \\
\text { conditions } \\
\end{array}$ & $\begin{array}{l}\text { Local jobs lose } \\
\text { their } \\
\text { attractiveness }\end{array}$ & $\begin{array}{l}\text { Locals leaving for } \\
\text { better opportunities, } \\
\text { decreasing population }\end{array}$ & $\begin{array}{l}\text { Small local market in all } \\
\text { aspects, generally low } \\
\text { incomes }\end{array}$ \\
\hline \multirow{2}{*}{$\begin{array}{l}\frac{1}{d} \\
\frac{0}{2} \\
\frac{2}{0} \\
\stackrel{1}{1} \\
\frac{1}{1}\end{array}$} & $\begin{array}{l}\text { Fragile local } \\
\text { labour market }\end{array}$ & $\begin{array}{l}\text { Competing for } \\
\text { the employees }\end{array}$ & $\begin{array}{l}\text { 'Eating up' local labour } \\
\text { market, suffering from } \\
\text { the lack of supplies }\end{array}$ & $\begin{array}{l}\text { Getting more difficult to find } \\
\text { young workers, difficult to } \\
\text { mobilize the elder, } \\
\text { experienced ones }\end{array}$ \\
\hline & $\begin{array}{l}\text { Lack of qualified } \\
\text { labour }\end{array}$ & $\begin{array}{l}\text { Limits of } \\
\text { growths and } \\
\text { expansion of } \\
\text { business }\end{array}$ & $\begin{array}{l}\text { Decreasing turnover, } \\
\text { increasing vulnerability }\end{array}$ & $\begin{array}{l}\text { Most of the interviewees have } \\
\text { stable clientele, but cannot } \\
\text { obtain more }\end{array}$ \\
\hline
\end{tabular}

Thus, the general conclusion of the case study is that manpower supply for employers in shrinking rural regions is becoming more and more of a challenge. In earlier parts of our study, we have shown the problem affecting the whole country i.e. that small towns are unable to retain the majority of their young inhabitants, which will continue to cause problems on the demand side of labour market. The perspectives of the studied enterprises are not very positive, most of them finding it a true problem that as they gradually lose their ageing qualified staff, it is hard or impossible to substitute them. Others do not plan so much ahead, and do not think about how their labour market status will change in five or ten years' time. Locally operating, viable enterprises thus undergo a selection process, their incomes typically not being enough for innovation and the necessary training. Through these processes a side-effect of demographic decline in rural settlements is encountered, which results in the decay of local economy and the deterioration of the originally weak competitiveness of small towns.

\section{Conclusions}

The population loss of small towns is quite substantial based on both the statistical data and our empirical surveys, possibly reaching the rate of $2 / 3$ in the case of the young age group, which raises the question of social sustainability in the long run. Outmigration is only partially compensated by the immigrating population who are normally made up of people of a lower social status. Outmigration tends to lead to increasingly distant target areas - to foreign countries in $15 \%$ of the cases in certain groups -, which fundamentally reduces the chances for them to ever return. Regrettably, it is the more qualified groups who tend to be on the move, and they are the ones subject to migrating away forever. Our interviews with enterprises confirmed 
the selective loss of young age groups in small towns: the qualitative composition of the remaining labour market clearly deteriorates.

We need to notice that our empirical surveys did not find evidence for the gender-selectivity of outmigration, which is described in a sort of peripheral rural regions (Leibert, 2016). However, there are some differences in the goals and methods of surveys, which may reveal the reasons for the differences. Our work did not analyse the rural regions as a whole, but only the small towns, which are, of course more urban, and the phenomenon connected with the rural masculinity, are somewhat less typical for them. Another, methodological aspect is that we only surveyed people holding a secondary school leaving exam, and the men who are more satisfied with local opportunities and environment, are choosing this school type in lower percentages.

According to both literature data and our empirical findings, small towns gradually loosen up on their force of gravity, their attraction zones becoming incidental and the towns themselves offering their environment fewer and fewer services that could strengthen their survival chances and central roles. Our investigations showed that people having completed their secondary school years in local institutions either continue their studies in higher education or plan their career on a higher level, sometimes in more distant locations. This process greatly reduces the chances of local intelligentsia to survive and have appropriate aftergrowth. As we have experienced, the shrinkage of small town's social capital has become highly significant, meaning an erosion of a feature that formerly gave the character of small town development and raised these towns out of their rural environment.

In many cases, the decline of small towns reaches a degree when it is already impossible to recruit human resources from their own attraction zones not only qualitatively but even in numbers. Besides leading to the disappearance of local intelligentsia, this process of decline also threatens enterprises relying on qualified personnel. Possibly, we have already reached a stage when not only the graduated staff, but also the qualified workers are among "luxury items" in the local labour market, this situation placing some of our small towns in a spiral, which can hardly be overcome on a local level.

The factors we have explored here about the migration of young people are problems, which are not specific to Hungary. The underlying reasons can partly be extended and generalised on the broader regional scale of East-Central Europe, and are partly general features arising from the special developmental characteristics of small towns. It seems that small towns are totally losing their attraction from the viewpoint of young people. This is true in spite of the fact that the demand for manpower on the other side (having predominantly qualitative components) could theoretically ensure the local employment of these young people. This research not having revealed motivations, only presents an estimation from statistical data, yet from our findings it can be stated that small towns are places that are simply not good enough for young people. In other words: the traditional values of small towns - which are also reflected by the expectations and responses of local enterprises - do not meet the ideas of this young generation.

\section{Acknowledgement}

The work of G. Pirisi was supported by the János Bolyai Research Scholarship of the Hungarian Academy of Sciences.

\section{Academic references}

[1] Alston, M. (2004). "'You don”t want to be a check-out chick all your life': the out-migration of young people from Australia's small rural towns', Australian Journal of Social Issues, The, 39(3), 299-313. Doi: 10.1002/j.1839-4655.2004.tb01178.x.

[2] Beluszky, P. (1999). Magyarország településföldrajza. Budapest - Pécs: Dialóg Campus.

[3] Besser, T. L. (2009). Changes in small town social capital and civic engagement, Journal of Rural Studies, 25(2), pp. 185-193. Doi: 10.1016/j.jrurstud.2008.10.005.

[4] Besser, T. L., Recker, N. \& Agnitsch, K. (2008). The Impact of Economic Shocks on Quality 
of Life and Social Capital in Small Towns, Rural Sociology, 73(4), 580-604. Doi: 10.1526/003601108786471530.

[5] Blaskó, Z. \& Gödri, I. (2014). Kivándorlás Magyarországról: szelekció és célország-választás az "új migránsok" körében, Demográfia, 57(4), 271-307.

[6] Broadway, M. J. (2000). Planning for change in small towns or trying to avoid the slaughterhouse blues. Journal of Rural Studies, 16(1), 37-46. Doi: 10.1016/S07430167(99)00038-8.

[7] Burdack, J. (2013). Lokal basierte Kleinstadtentwicklung in östlichen Europa. Potenziale, Probleme und Praktikum - Eine Einführung. In Burdack, J. \& Kriszán, Á, eds., Kleinstädte in Mittel- und Osteuropa: Pespektiven und Strategien Lokaler Entwicklung (pp. 5-12). Leipzig: Institut für Länderkunde.

[8] Domina, T. (2006). What clean break? Education and nommetropolitan migration patterns, 1989-2004. Rural Sociology, 71(3), 373-398. Doi: 10.1526/003601106778070626.

[9] Elsasser, H. (1998). Ist eine Kleinstadt mehr als eine kleine Stadt? In Munduch, E. M. \& Spiegler, A., eds.. Kleinstädte. Motoren in ländlichen Raum. Tagungsband anlässlich des ersten mitteleuropäischen Kleinstadtsymposiums in Murau (pp. 10-17). Wien: Österreichisches Kuratorium für Landtechnik und Landentwicklung.

[10] Enyedi, G. (2012). Városi világ. Budapest: Akadémiai Kiadó.

[11] Faluvégi, A. \& Tipold, F. (2007). A területfejlesztés kedvezményezett térségeinek 2007. évi besorolása. Területi Statisztika, 10(6), 523-540.

[12] Fertner, C., Groth, N. B., Herslund, L. \& Carstensen, T. A. (2015). Small towns resisting urban decay through residential attractiveness. Findings from Denmark. Geografisk Tidsskrift 115(2), 119-132. Doi: 10.1080/00167223.2015.1060863.

[13] Gödri, I. (2015). Nemzetközi vándorlás. In Monostori, J., Öri, P. \& Spéder, Z. Demográfiai portré 2015 (pp. 187-211). Budapest: Központi Statisztikai Hivatal.

[14] Haase, A., Bernt, M., Großmann, K., Mykhnenko, V. \& Rink, D. (2016). Varieties of shrinkage in European cities. European Urban and Regional Studies, 23(1), 86-102. Doi: $10.1177 / 0969776413481985$.

[15] Haase, D. (2008). Urban ecology of shrinking cities: an unrecognized opportunity? Nature and Culture 3(1), 1-8. Doi: 10.3167/nc.2008.030101.

[16] Hannemann, C. (2003). Urbanistische Probleme und kulturelle Perspektiven der ostdeutschen Kleinstadtentwicklung. In Zimmermann, C., ed., Kleinstädte in der Moderne (pp. 157-182). Stuttgart: Jan Thorbecke Verlag.

[17] Hollander, J. B. (2010). Can a City Successfully Shrink? Evidence from Survey Data on Neighborhood Quality. Urban Affairs Review $\frac{47(1),}{129-141 .}$ Doi: $10.1177 / 1078087410379099$.

[18] Ježek, J. (2011). Small towns attractiveness for living, working and doing business. Case study the Czech Republic. In Ježek, J. \& Kaňka, L., eds., Competitiveness and Sustainable Development of the Small Towns and Rural Regions in Europe (pp. 4-11). Plzeň: University of West Bohemia in Pilsen.

[19] Kaczmarek, U. \& Konecka-Szydłowska, B. (2013). Perspectives for development of small towns in Wielkopolska voivodeship. In Burdack, J. \& Kriszán, Á, eds., Kleinstädte in Mittelund Osteuropa: Pespektiven und Strategien Lokaler Entwicklung (pp. 66-88). Leipzig: Institut für Länderkunde.

[20] Kapitány, B. \& Rohr, A. (2014). Kivándorlás Magyarországról - egy új becslési eljárás eredményei. In Spéder, Z., ed., A család vonzásában: Tanulmányok Pongrácz Tiborné tiszteletére (pp. 67-85). Budapest: KSH Népességtudományi Kutatóintézet.

[21] Kolb, A. (2004). Die Kleinstadt auf dem Weg in die Moderne. Pro-Regio-Online, 4, 12-134. 
[22] Konecka-Szydłowska, B. \& Kaczmarek, U. (2010). Small town development and social capital in Poland: the casus Łobez and Słupca. In Borsig A., Burdack J. \& Knappe E., eds., Small towns in Eastern Europe: local networks and urban development (pp. 72-89). Leipzig: Leibnitz-Institut für Länderkunde.

[23] Kovács, Z. (2010). A szocialista és posztszocialista urbanizáció értelmezése. In Barta, G., Beluszky, P., Földi, Z. \& Kovács, K., eds., A területi kutatások csomópontjai (pp. 141-157). Pécs: MTA Regionális Kutatások Központja.

[24] Kwiatek-Sołtys, A. (2006). Migration attractiveness of small towns in the Małoposka Province. Bulletin of Geography. Socio-economic Series, 5(1), 155-160.

[25] Kwiatek-Soltys, A. (2015). Population changes as litmus paper of the socio-economic development level of small towns in Poland. Annales Universitatis Paedagogicae Cracoviensis Studia Geographica 8(1), 39-53.

[26] Kwiatek-Soltys, A. \& Mainet, H. (2014). Quality of Life and Attractiveness of Small Towns: A Comparison of France and Poland. Quaestiones Geographicae 33(2), 103-113. Doi: 10.2478/quageo-2014-0019.

[27] Leetmaa, K., Kriszan, A., Nuga, M. \& Burdack, J. (2015). Strategies to Cope with Shrinkage in the Lower End of the Urban Hierarchy in Estonia and Central Germany. European Planning Studies 23(1), 147-165. Doi: 10.1080/09654313.2013.820100.

[28] Leibert, T. (2016). She leaves, he stays? Sex-selective migration in rural East Germany. Journal of Rural Studies, 43(2), 267-279. Doi: 10.1016/j.jrurstud.2015.06.004.

[29] Leibert, T., Montanari, G. \& Wiest, K. (2015). Rural peripheralization - urban polarization? Significance of gendered mobility in Central Germany. In Lang, T., Henn, S., Sgibnev, V. \& Ehrlich, K., eds., Understanding geographies of polarization and peripherialization. Perspectives from Central and Eastern Europe (pp. 115-134). Basingstoke: Palgrave Macmillan.

[30] Leibert, T. \& Wiest, K. (2016). The interplay of gender and migration in Europe's remote and economically weak rural regions: Introduction to a special issue. Journal of Rural Studies, 43(2), 261-266. Doi: 10.1016/j.jrurstud.2016.01.007.

[31] Martinez-Fernandez, C., Audirac, I., Fol, S. \& Cunningham-Sabot, E. (2012). Shrinking Cities: Urban Challenges of Globalization. International Journal of Urban and Regional Research 36(2), 213-225. Doi: 10.1111/j.1468-2427.2011.01092.x.

[32] Mayer, H. \& Knox, P. (2010). Small-Town Sustainability: Prospects in the Second Modernity. European Planning Studies, 18(10), 1545-1565. Doi: 10.1080/09654313.2010.504336.

[33] Molnár, E. (2013). Egy zsugorodó iparág újrapozicionálásának kérdőjelei: Magyarország cipőgyártása a rendszerváltás után. Tér és Társadalom 27(4), 95-114. Doi: 10.17649/TET.27.4.2577.

[34] Németh, Z. (2011). Az urbanizáció és a térbeli társadalomszerkezet változása Magyarországon 1990 és 2001 között. Budapest: Központi Statisztikai Hivatal.

[35] Nugin, R. (2014). "I think that they should go. Let them see something". The context of rural youth's out-migration in post-socialist Estonia. Journal of Rural Studies. 34, 51-64. Doi: 10.1016/j.jrurstud.2014.01.003.

[36] Pallagst, K. M., Wiechmann, T. \& Martinez-Fernandez, C. (2014). Shrinking Cities International Perspecitves and Policy Implications. Routledge Advances in Geography. New York - London: Routledge.

[37] Pirisi, G. (2014). Zsugorodó kisvárosok - A demográfiai hanyatlás néhány lokális aspektusa. Településföldrajzi Tanulmányok 3(2), 35-46.

[38] Pirisi, G. \& Trócsányi, A. (2015). Between shrinking and blooming: the crossroad of small towns' urbanisation in Hungary. Annales Universitatis Paedagogicae Cracoviensis Studia Geographica 8(1), 12-28. 
[39] Putnam, R. D. (2001). Bowling alone: The collapse and revival of American community. New York: Simon and Schuster.

[40] Raagmaa, G. (2015). Territorial governance and core-periphery relations: The implications of European policy concepts for Central and Eastern Europe. In Lang, T., Henn, S., Sgibnev, V. \& Ehrlich, K., eds., Understanding geographies of polarization and peripherialization. Perspectives from Central and Eastern Europe (pp. 115-134). Basingstoke: Palgrave Macmillan.

[41] Schilling, J. \& Logan, J. (2008). Greening the Rust Belt. Journal of the American Planning Association 74(4), 451-466. Doi: 10.1080/01944360802354956.

[42] Slavík, V. (2002). Small Towns of the Slovak Republic within the transformation stage. Acta Facultatis Studiorum Humanitatis et Naturae Universitatis Prešoviensis, Folia Geographica 5(1), 146-154.

[43] Trócsányi, A., Pirisi, G. \& Makkai, B. (2014). A szellemi tőke szerepe a várossá nyilvánításokban. Educatio 23(6), 438-450.

[44] Troeger-Weiß, G. \& Domhardt, H.-J. (2009). Germany's Shrinkage on a Small Town Scale. In Pallagst, K. M., ed., The Future of Shrinking Cities: Problems, Patterns and Strategies of Urban Transformation in a Global Context (pp. 161-168). Berkeley, CA: University of California.

[45] Vaishar, A. \& Greer-Wootten, B. (2006). Sustainable development in Moravia: an interpretation of the role of the small-town sector in transitional socioeconomic evolution. In Bochniarz, Z. \& Cohen, G. B., eds., The environment and sustainable development in the new central Europe (pp. 217-231). New York: Berghahn.

[46] Vaishar, A. \& Zapletalová, J. (2009). Small towns as centres of rural micro-regions. European Countryside 1(2), 70-81. Doi: 10.2478/v10091-009-0006-4.

[47] Vaishar, A., Zapletalová, J. \& Nováková, E. (2016). Between Urban and Rural: Sustainability of Small Towns in the Czech Republic. European Countryside, 8(4), 351-372. Doi: 10.1515/euco-2016-0025.

[48] Wirth, P., Elis, V., Müller, B. \& Yamamoto, K. (2016). Peripheralisation of small towns in Germany and Japan - Dealing with economic decline and population loss. Journal of Rural Studies, 47, Part A, 62-75. Doi: http://dx.doi.org/10.1016/j.jrurstud.2016.07.021.

[49] Woods, M. (2005). Rural geography: Processes, responses and experiences in rural restructuring. Thousand Oaks, CA: Sage.

[50] Zuzańska-Żyśko, E. (2003). Population types of small towns in Silesian Province. Bulletin of Geography. Socio-economic Series 2(1), 143-149. 